\title{
Expression of Heat-stable and Putative Dehydrin Proteins during Nonacclimated and Cold-acclimated Conditions in Several Tuber-bearing Solanum Species
}

\author{
Björn H. Karlsson ${ }^{1}$ and Jiwan P. Palta ${ }^{2}$ \\ Department of Horticulture, 1575 Linden Drive, University of Wisconsin, Madison, WI 53706-1590
}

\begin{abstract}
ADDITIONAL INDEX wORDS. cold-regulated protein, cryoprotection, Solanum tuberosum, Solanum acaule, Solanum sanctae rosea, Solanum commersonii, Solanum cardiophyllum
\end{abstract}

\begin{abstract}
Recent studies suggest cold-regulated heat-stable proteins mitigate the potential damaging effects of low water activity associated with freezing. A proposed function of these proteins is stabilization of enzymes during exposure of plants to subzero temperatures. To test this hypothesis for tuber-bearing Solanum L. species we determined the quantitative expression of heat-stable proteins, the qualitative changes in dehydrin proteins, and the capacity of heatstable proteins to cryoprotect a freeze-thaw labile enzyme lactate dehydrogenase (LDH). We used five tuber-bearing Solanum species (S. tuberosum L. 'Red Pontiac', S. acaule Bitter, S. sanctae rosea Hawkes, S. commersonii Dunal, and S. cardiophyllum Bitter ), which vary in nonacclimated relative freezing tolerance (NA RFT), acclimated relative freezing tolerance (AC RFT), and acclimation capacity (ACC). The protein fraction containing a mixture of heat-stable proteins demonstrated cryoprotective capacities greater or equal to other cryoprotective compounds (bovine serum albumin, polyethylene glycol, glycerol, and sucrose). Heat-stable proteins extracted from acclimated $S$. commersonii had superior cryoprotective capacity than those extracted from nonacclimated $S$. commersonii plants. Interestingly, in the presence of these proteins extracted from acclimated plants (in S. commersonii and S. sanctae rosea), LDH activity was elevated above that of unfrozen controls. No quantitative relationships were found between heat-stable protein concentration and NA RFT, AC RFT, or ACC among the five species. This was also true for dehydrin protein expression. Cold acclimation treatment resulted in increased dehydrin expression for acclimating and nonacclimating species. In three of the cold acclimating species ( $S$. acaule, $S$. sanctae rosea, and $S$. commersonii), an increase in dehydrin expression may play a role in increased freezing tolerance during cold acclimation. In the cold sensitive, nonacclimating species (S. tuberosum and $S$. cardiophyllum), however, an increase in dehydrin level maybe related to the response of these species to changed (perhaps stressful) environment during cold treatment. By exploiting the genetic variation in NA RFT and ACC for five tuber-bearing species, we were able to gain new insight into the complexity of the relationship between heat-stable protein and cold response.
\end{abstract}

Upon exposure to cold temperatures, plant species synthesize proteins that are believed to mitigate the damaging effects of low water activity associated with freezing (Guy, 1990). Though the mechanism by which specific proteins impart increased freezing tolerance in plants remains largely unknown, insights into their function may lie in properties common to several cold induced proteins: hydrophilicity and the ability to remain soluble during exposure to high heat (Thomashow et al., 1993). Dehydrins are one class of protein identified as heat-stable and often upregulated during cellular stresses involving desiccation (cold, heat, drought). Heat-stable proteins are suggested to act as cryoprotectants to enzymes or organelles sensitive to freeze-induced dehydration (Blackman et al., 1995; Close et al., 1993; Jacobsen and Shaw, 1989) and to protect desiccation-sensitive cellular constituents (Volger and Heber, 1975). COR15a, a cold induced Arabidopsis thaliana (L.) Heynh. heat-stable protein, was found to have cryoprotective activity $10^{6}$ times greater than sucrose and $>100$ times greater than bovine serum albumin (BSA) (Lin and

Received for publication 20 Aug. 1998. Accepted for publication 9 Feb. 1999. We thank Timothy Close for providing dehydrin antibodies. Thanks go to James Harbage, Cortland Griswold, and Laurie Weiss for their valuable assistance and Julie Stone, whose preliminary results inspired the current study. We also thank John Stier and Robert Hanneman for critical review of this manuscript. This work was supported by the College of Agriculture and Life Sciences and by USDA/NRI grant 93-37100-8924. Use of trade names does not imply endorsement of products mentioned or criticism of similar ones not named. The cost of publishing this paper was defrayed in part by the payment of page charges. Under postal regulations, this paper therefore must be hereby marked advertisement solely to indicate this fact.

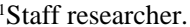

${ }^{2}$ Professor of horticulture; to whom reprint requests should be addressed.
Thomashow, 1992). More recent work demonstrated that overexpression of $\mathrm{CBF} 1$, a cold-regulated (COR) regulatory element and DNA transcriptional activator, induced several COR proteins and increased freezing tolerance in nonacclimated Arabidopsis plants (Jaglo-Ottosen et al., 1998).

Evidence for cold-regulated heat-stable proteins (including dehydrins) have been presented for peach (Prunus persica L.) (Arora and Wisniewski, 1994), Brassica napus (Boothe et al., 1995), grape (Vitis labruscana L. 'Concord') (Salzman et al., 1996), Arabidopsis (Artus et al., 1996), wheat (Triticum aestivum L.) (Danyluk et al., 1994), and brome grass (Bromis inermis Leyss 'Manchar') (Robertson et al., 1994). For example, recent evidence in peach indicate earlier and greater accumulation of dehydrin transcript and protein for deciduous (more cold-hardy) as compared to evergreen type (less cold-hardy) (Artlip et al., 1997). Other studies have demonstrated accumulations of heatstable proteins in sensitive vascular tissues during cold acclimation in winter wheat (Triticum aestivum L.) 'Fredrick' (Houde et al., 1995) and alfalfa (Medicago sativa L. Apica and Trek) (Kawczynski and Dhindsa, 1996). Considerable complexity curtails any suggestion, however, that heat-stable proteins are used universally by a plant to mitigate damage due to freeze-thaw conditions. For example, Pan et al. (1994) mapped dehydrin loci where quantitative trait loci (QTL) for cold-hardiness traits have not been detected. Further highlighting the complex relationship between desiccation stress and dehydrin, Robertson and Chandler (1994) reported constitutive expression of dehydrin in pea (Pisum sativum L. 'Greenfeast'). In a preliminary report we suggested that despite extensive evidence of a role for these proteins in 
freezing tolerance, they cannot alone be responsible for variations in freezing tolerance in segregating potato populations (Karlsson et al., 1994).

By exploiting the genetic variation in nonacclimated relative freezing tolerance (NA RFT) and acclimation capacity (ACC) for five tuber-bearing species we attempted to gain new insight into the complexity of the relationship between heat-stable protein and cold response. To our knowledge no study has investigated the relationship between dehydrin protein expression and cold hardiness in Solanum species and little or no information has been established on the cryoprotective role of heat-stable proteins in these species.

\section{Materials and Methods}

Chemicals. All chemicals listed were purchased from Sigma (St. Louis, Mo.) unless otherwise indicated.

Plant material and Culture conditions. Seeds of $S$. cardiophyllum PI 184762, S. sanctae-rosea PI 473200, S. acaule PI 472659, and S. commersonii PI 472834 were obtained from the potato introduction station (Sturgeon Bay, Wis.) and were germinated in sterile culture conditions. An individual seedling was selected and multiplied to obtain plantlets which were grown and maintained in sterile culture on MS medium (Murashige and Skoog, 1962). Plantlets of S. tuberosum L. 'Red Pontiac' were propagated in sterile culture using nodal cuttings from a single certified seed tuber sprout. Plantlets were potted in Jiffy Mix (JP, West Chicago, Ill.) with 1 peat : 1 vermiculite in 8 -L pots and grown in a $3.7 \times 2.6-\mathrm{m}$ controlled environment room at the University of Wisconsin Biotron facility (Madison, Wis.).

Nonacclimated growth conditions were $20 / 18{ }^{\circ} \mathrm{C}$ light/dark temperatures, with a $14-\mathrm{h}$ photoperiod of $400 \mu \mathrm{mol} \cdot \mathrm{m}^{-2} \cdot \mathrm{s}^{-1}$ photosynthetically active radiation $(P A R)$ from cool-white fluorescent lamps (Phillips F96T12-CW-VHO) (Steffan and Palta, 1986). Relative humidity was maintained at $\approx 70 \% \pm 5 \%$. Hoagland and Arnon nutrient solution (Hoagland and Arnon, 1950) was used at one-fourth strength and delivered to excess four times daily. Coldacclimation conditions were $4 / 2{ }^{\circ} \mathrm{C}$ light/dark temperatures with a $14-\mathrm{h}$ photoperiod of $100 \mu \mathrm{mol} \cdot \mathrm{m}^{-2} \cdot \mathrm{s}^{-1}$ for $14 \mathrm{~d}$. These conditions produced fully acclimated plants (Steffan and Palta, 1986).

Freezing tolerance determination. Freeze-thaw experiments were conducted, as previously described (Steffan and Palta, 1986; Stone et al. 1993), by excising fully expanded leaflets and placing them in glass tubes submerged in a glycol-containing controlled temperature bath. Controls were immediately placed on ice while others were cooled at $1^{\circ} \mathrm{C} \cdot \mathrm{h}^{-1}$ and three samples were taken at each of several freezing temperatures. Following thawing over ice for $12 \mathrm{~h}$, the amount of ion leakage from leaf samples was determined by conductivity measurement. The leaf samples were autoclaved and total ion leakage measured. The percent ion leakage (ion leakage following injury and ion leakage from same samples after autoclaving) was plotted as a function of freezing temperature. NA RFT and cold acclimated relative freezing tolerance (AC RFT) were determined from the midpoint between maximum and minimum ion leakage values before and after cold acclimation (Sutinen et al., 1992). ACC was calculated as the gain in relative freezing tolerance following cold acclimation (|AC RFT $\mid$ - |NA RFT $\mid$ ).

EXTRACTION AND DETERMINATION OF TOTAL AND HEAT-STABLE PROTEINS. Soluble proteins were extracted in triplicate from fully expanded terminal leaflets using 8-week old plants grown in nonacclimated conditions and from a parallel set of plants grown under the same nonacclimated conditions followed by 2 weeks of cold acclimation. The leaves were excised, immediately frozen in liquid $\mathrm{N}_{2}$ and ground in a mortar to a fine powder. A slurry of each sample was prepared by adding $3 \mathrm{~mL}$ extraction buffer $(10 \mathrm{~mm}$ Tris-HCl, pH 7, containing $1 \mathrm{~mm}$ PMSF) per gram tissue (fresh weight). The slurry was centrifuged at $8000 g_{\mathrm{n}}$ for $20 \mathrm{~min}$ and the supernatant centrifuged again at $48,000 g_{\mathrm{n}}$ for $2.5 \mathrm{~h}$ to maximize microsomal membrane removal.

To isolate heat-stable proteins, the supernatant was boiled for $10 \mathrm{~min}$, cooled on ice and centrifuged at 20,000 $g_{\mathrm{n}}$ for $30 \mathrm{~min}$ to remove the precipitated proteins (Close et al, 1989). The resulting supernatant, containing heat-stable proteins, was stored at $-80^{\circ} \mathrm{C}$. The concentration of heat-stable protein was determined in duplicate from each of three extractions using a modification of the Lowry assay (Lowry et al. 1951) in which proteins were TCA precipitated on ice with an RNA carrier [type III, baker's yeast (Sigma)] to remove interfering substances prior to spectrophotometric determination (Polacheck and Cabib, 1981). A standard curve was constructed using BSA. SDS-PAGE profiles were run of heat-stable proteins extracted from nonacclimated (NA) and cold acclimated (ACC) samples.

LDH CRYOPROTECTIVE ASSAY. For the assay, heat-stable proteins were precipitated by diluting 3-fold in acetone on ice for 1 $h$, centrifuged, rinsed in ice-cold acetone and dried under $\mathrm{N}_{2}$ gas. The resulting pellet was resuspended in $10 \mathrm{~mm}$ potassium phosphate buffer ( $\mathrm{pH} 7.5$ ) and Lowry protein quantification was repeated using BSA as a standard. Recovery of acetone precipitated protein was generally $80 \%$ to $90 \%$. The LDH assay was carried out as described by Tamiya et al. (1985). In a microfuge tube, $50 \mu \mathrm{L}$ of $1.75 \mu \mathrm{g} \cdot \mathrm{mL}^{-1}$ of the freeze-labile enzyme lactate dehydrogenase (LDH) (EC\# 1.1.1.27. rabbit muscle lactate dehydrogenase-5[M4] isoenzyme type V-S; Sigma) in $10 \mathrm{~mm}$ potassium phosphate buffer $(\mathrm{pH} 7.5)$ was added to $50 \mu \mathrm{L}$ of a range of heat-stable protein concentrations $\left(0-10\right.$ and $\left.50 \mu \mathrm{g} \cdot \mathrm{mL}^{-1}\right)$. Heatstable proteins were pooled from triplicate extractions into a single sample and combined with LDH in different concentrations in the same buffer. The LDH and heat-stable protein mixtures were placed in a freezer at -18 to $-22^{\circ} \mathrm{C}$ for $20 \mathrm{~h}$, thawed at room temperature for $6 \mathrm{~min}$, and assayed for enzyme activity. The temperature of the solution mixture was monitored continuously with a thermocouple. Unfrozen LDH samples were assayed for enzyme activity at the time of addition to heat-stable proteins as well as the next day to establish prefreeze-thaw activity (100\%). Relative LDH activity (\%) resulting from cryoprotection by heatstable proteins and standards was determined by calculating activity of frozen LDH at each concentration as a percentage of prefreeze LDH activity. The activity insensitive to freeze-thaw stress in the absence of cryoprotectant was subtracted from the values plotted $(\approx 10 \%)$ to equalize day to day differences in assay conditions. The assay consisted of sampling, adding $20 \mu \mathrm{L}$ of $\mathrm{LDH}+$ heat-stable protein mixture to $1 \mathrm{~mL}$ of an LDH assay mix at $25^{\circ} \mathrm{C}$ containing $80 \mathrm{~mm}$ tris- $\mathrm{HCl} \mathrm{pH} \mathrm{7.5,} 100 \mathrm{~mm} \mathrm{KCl}, 2 \mathrm{~mm}$ pyruvic acid, and $0.3 \mathrm{~mm} \mathrm{NADH}$. The rate of decrease in absorbance was measured at $340 \mathrm{~nm}$ at $25^{\circ} \mathrm{C}$ using a Beckman spectrophotometer DU-50 during the first 3 min of oxidation of NADH and was used to calculate LDH activity in the linear range. A third-order polynomial fit was used to determine the concentration of the additive required for $50 \%$ cryoprotection of $\mathrm{LDH}$ activity $\left(\mathrm{CP}_{50}\right)$ following freeze/thaw cycle. BSA, polyethylene glycol (PEG), sucrose (Mallinkrodt Chemical, Inc., Paris, Ky.), and glycerol were also assayed for cryoprotection of LDH in the manner described above.

SPECIFIC IMMUNOLOGICAL DETECTION OF DEHYDRIN. Western immunoblotting followed techniques of Birkett et al. (1985) with Millipore Immobilon-P transfer membrane (pore size $0.45 \mu \mathrm{m}$; 
Table 1. Relative freezing tolerances $\left({ }^{\circ} \mathrm{C}\right)$ of Solanum species as measured by ion leakage method. Tests were conducted before (nonacclimated) and after cold acclimation period (acclimated). Acclimation capacity is reported as increase in freezing tolerance following cold acclimation. Relative freezing tolerances are reported from an ion leakage evaluation and have SE $\pm 0.2^{\circ} \mathrm{C}$.

\begin{tabular}{lccc}
\hline \hline & & \multicolumn{2}{c}{ Relative freezing tolerance $\left({ }^{\circ} \mathrm{C}\right)$} \\
\cline { 2 - 4 } $\begin{array}{l}\text { Solanum } \\
\text { species }\end{array}$ & Nonacclimated $^{\mathrm{z}}$ & Acclimated $^{\mathrm{y}}$ & $\begin{array}{c}\text { Acclimation } \\
\text { capacity }^{-}\end{array}$ \\
\hline S. cardiophyllum (PI 184762) & -1.8 & -2.6 & 0.8 \\
S. tuberosum L. Red Pontiac & -2.8 & -2.8 & 0.0 \\
S. sanctae-rosea (PI 473200) & -3.6 & -5.7 & 2.1 \\
S. acaule (PI 472659) & -4.2 & -5.9 & 1.7 \\
S. commersonii (PI 472834) & -6.1 & -9.7 & 3.6 \\
\hline
\end{tabular}

ZPlants were grown in a regime of $20 / 18^{\circ} \mathrm{C}$ day/night, $14 \mathrm{~h}$ light.

yPlants 6 weeks old grown at above conditions were cold acclimated in a regime of $4 / 2{ }^{\circ} \mathrm{C}$ day/night, $14 \mathrm{~h} \mathrm{light} \mathrm{for} 14 \mathrm{~d}$.

xotato introduction (PI) identification number at the potato introduction station, Sturgeon Bay, Wis.

filter type PVDF). Preimmune sera and antidehydrin antibodies specific for the conserved lysine-rich peptide of most plant dehydrins were provided by T. Close (Univ. of Calif., Riverside). The antibody was diluted 1/500 and alkaline phosphatase conjugated antirabbit $\operatorname{IgG}$ (whole molecule) antiserum was diluted 1/ 2000. Specific detection of dehydrin protein was obtained by incubation with antidehydrin antibodies compared to preimmuneserum. To establish immunological specificity of dehydrin antibodies, an SDS-PAGE profile $(18 \times 20 \mathrm{~cm})$ was prepared with identical halves loaded ( $25 \mu \mathrm{g}$ per lane) with cold acclimated heat-stable protein extracts. Just before incubation in primary antibody, the membrane was cut in half and each half was treated identically with the exception of dehydrin antibody vs. preimmune serum incubation. Dehydrin antibodies were directed against a peptide of a highly conserved consensus region (CTGEKKGIMDKIKEKLPGQH) characteristic of dehydrin proteins with apparent molecular mass $5-150 \mathrm{kD}$ depending on plant species (Close et al, 1993). For westerns, large gels $(18 \times 20 \mathrm{~cm})$ were loaded based on fresh weight $(40 \mu \mathrm{L}$ extract per lane $)$ and on equal protein basis ( $25 \mu \mathrm{g}$ per lane) with samples pooled from two to three extractions. Silver stained gels of protein samples were run as a check for protein concentration. Immunoblots were also run two to three times to check against loading error.

\section{Results}

HEAT-STABLE PROTEIN CONCENTRATION AND RELATIVE FREEZING TOLERANCE. The relative freezing tolerance of five tuber-bearing Solanum species before and after cold acclimation treatment were similar to earlier findings (Chen and Li, 1980; Palta et al., 1981) (Table 1). In Fig. 1, SDS-PAGE shows the array of heat-stable proteins for each species with evidence of increase in some bands (25-29 kD). The $42 \mathrm{kD}$ putative dehydrin bands do not appear visually discernable in this profile. In the five species studied, the concentration of heat-stable proteins on a fresh weight basis (Table 2) did not correlate either with NA RFT or with AC RFT $\left(r^{2}=0.07\right.$ and 0.01 , respectively). All species are known to be chilling tolerant (no injury within $14 \mathrm{~d}$ of chilling) and remained turgid during the entire cold acclimation period, hence water content was considered to be similar before and after cold acclimation. For each species studied, the concentration of heat-stable proteins increased following cold acclimation treatment (Table 2). The level of heat-stable protein concentration increase following cold acclimation, however, was slightly though not significantly inversely correlated with ACC (increased freezing tolerance following cold acclimation: $r^{2}=0.57:(0.1$ and 0.5$)$. Thus no significant quantitative relationship was found between concen- tration of heat-stable proteins on fresh weight basis and NA RFT, AC RFT or ACC.

Heat-stable proteins as a percentage of total soluble protein ranged from $6 \%$ to $8 \%$ during nonacclimating conditions and ranged from $5 \%$ to $14 \%$ among the species following exposure to acclimating conditions; thus constituting a significant fraction of all soluble proteins. There was no association between ACC and the increase in heat-stable proteins as a fraction of total soluble proteins following cold acclimation. The greatest increase in heatstable protein concentration was in a nonacclimating type $S$. tuberosum while two cold acclimating species, $S$. commersonii and $S$. acaule, demonstrated a reduction in heat-stable proteins as a fraction of total soluble proteins following cold acclimation.

DEHYDRIN EXPRESSION IN FIVE SPECIES. Specific detection of dehydrin protein was established by incubation with antidehydrin antibodies compared to preimmuneserum. Subsequent gels were loaded both on equal protein (Fig. 2) and fresh weight basis (not shown). The dehydrin band intensity varied slightly between these loading strategies but the relationship among species were nearly identical for purposes of comparing dehydrin expression. Western immunoblotting demonstrated that, except for S. sanctae rosea, dehydrin increased markedly following cold acclimation. Hardy species, S. commersonii and S. acaule, show the most intense bands following acclimation (Fig. 2). The moderately hardy species $S$. sanctae rosea did not appear to increase dehydrin though it was able to acclimate $\left(\right.$ ACC $\left.=1.7^{\circ} \mathrm{C}\right)$. Sensitive species-S. cardiophyllum and S. tuberosum-also increased dehydrin expression following cold acclimation with a more

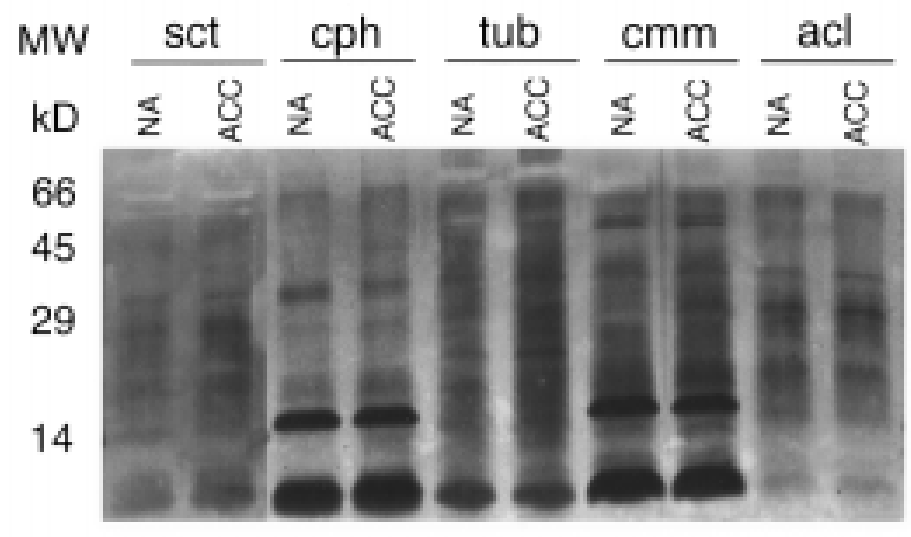

Fig. 1. SDS-PAGE profiles of heat-stable proteins extracted from nonacclimated (NA) and cold acclimated (ACC) Solanum species: S. cardiophyllum (cph), S. sanctae-rosea (sct), S. acaule (acl), S. commersonii (cmm), and S. tuberosum (tub) L. 'Red Pontiac'. Each lane was loaded on an equal protein basis with $60 \mu \mathrm{g}$. 
Table 2. Heat stable and total protein values for five Solanum species. Proteins were extracted from terminal leaf samples grown in nonacclimated and cold acclimated conditions. Samples were extracted and assayed in triplicate by modified Lowry protein assay and reported based on fresh weight $(\mathrm{FW})$ leaf tissue. Errors are reported as \pm SE.

\begin{tabular}{|c|c|c|c|c|}
\hline \multirow{3}{*}{$\begin{array}{l}\text { Solanum } \\
\text { species }\end{array}$} & \multicolumn{4}{|c|}{$\begin{array}{l}\text { Protein concn } \\
\left(\mathrm{mg} \cdot \mathrm{g}^{-1} \mathrm{FW}\right)\end{array}$} \\
\hline & \multicolumn{2}{|c|}{ Heat stable } & \multicolumn{2}{|c|}{ Total } \\
\hline & Nonacclimated $^{\mathrm{z}}$ & Acclimated $^{\mathrm{y}}$ & Nonacclimated & Acclimated \\
\hline S. cardiophyllum (PI 184762) & $0.77 \pm 0.01$ & $1.19 \pm 0.03$ & $10.0 \pm 0.4$ & $13.4 \pm 1.0$ \\
\hline S. tuberosum L. Red Pontiac & $0.54 \pm 0.01$ & $1.46 \pm 0.05$ & $8.8 \pm 0.4$ & $10.1 \pm 0.3$ \\
\hline S. sanctae-rosea (PI 473200) & $0.54 \pm 0.03$ & $0.79 \pm 0.05$ & $8.0 \pm 0.2$ & $8.8 \pm 0.7$ \\
\hline S. acaule (PI 472659) & $0.35 \pm 0.01$ & $0.51 \pm 0.02$ & $6.5 \pm 0.3$ & $9.6 \pm 0.8$ \\
\hline S. commersonii (PI 472834) & $1.01 \pm 0.03$ & $1.25 \pm 0.05$ & $12.4 \pm 0.6$ & $16.3 \pm 0.4$ \\
\hline
\end{tabular}

ㄹants were grown in a regime of $20 / 18^{\circ} \mathrm{C}$ day/night, $14 \mathrm{~h}$ light.

yPlants 6 weeks old grown at above conditions were cold acclimated in a regime of $4 / 2{ }^{\circ} \mathrm{C}$ day/night, $14 \mathrm{~h} \mathrm{light} \mathrm{for} 14 \mathrm{~d}$.

${ }^{x}$ Potato introduction (PI) identification number at the potato introduction station, Sturgeon Bay, Wis.

\section{A Equal Protein Basis}

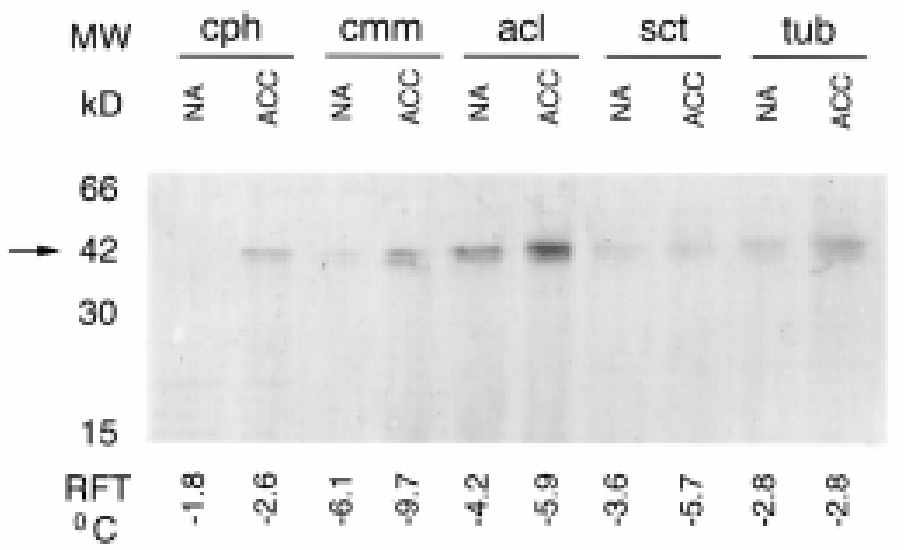

Fig. 2. Immunoblot of dehydrins from five tuber-bearing Solanum species: $S$. cardiophyllum (cph), S. sanctae-rosea (sct), S. acaule ( $\mathrm{acl})$, S. commersonii (cmm), and S. tuberosum (tub) L. 'Red Pontiac'. Soluble proteins were extracted in triplicate from fully expanded terminal leaflets using 8-week-old plants grown in nonacclimating conditions and from a parallel set of plants grown under the same nonacclimating conditions and then subjected to cold acclimation for 2 weeks. Each lane was loaded on equal protein basis $(25 \mu \mathrm{g})$. Relative freezing tolerances (RFTs) are reported from an ion leakage evaluation and have $\mathrm{SE} \pm 0.2^{\circ} \mathrm{C}$.

substantial band appearing in the latter. Other than $S$. sanctae rosea, sensitive species $S$. cardiophyllum expressed the lowest level of dehydrin following acclimation. In summary, there appeared to be no systematic relationship of dehydrin expression with NA RFT, AC RFT, and ACC among the five species studied.

LDH CRYOPROTECTIVE ASSAY. The LDH cryoprotective assay revealed interesting qualitative differences in heat-stable proteins among several species (Table 3 ). On an equal protein basis, heatstable proteins extracted from acclimated $S$. commersonii had a much higher cryoprotective activity than the heat-stable proteins from nonacclimated $S$. commersonii (Fig. 3). Following cold acclimation, the amount of heat-stable proteins from the freezingsensitive and nonacclimating S. tuberosum L. 'Red Pontiac', required to confer $50 \%$ cryprotection $\left(\mathrm{CP}_{50}\right)$ was 2 to 2.5 times more than freezing-tolerant and acclimation able $S$. commersonii (Fig. 3) and S. acaule (Table 3). Though S. acaule and S. sanctae rosea were able to increase freezing tolerance after acclimation by 1.7 and $2.1^{\circ} \mathrm{C}$, respectively, no significant differences between $\mathrm{CP}_{50}$ values were noted between nonacclimated and acclimated states in these species (Table 3). Freezing-sensitive $S$. cardiophyllum showed no significant change in concentration of heat-stable proteins required for $\mathrm{CP}_{50}$. Although $\mathrm{S}$. sanctae rosea and $S$. tuberosum required nearly the same concentration of heatstable proteins to confer $\mathrm{CP}_{50}$ before and after cold acclimation, there were substantial differences among their NA RFT and ACC RFT values (Table 1). Heat-stable proteins extracted from acclimated $S$. commersonii tissues conferred slightly greater cryoprotection to LDH than BSA (Fig. 4), a protein with known cryoprotective capacity (Grieff and Kelly, 1966; Tamiya et al., 1985). These proteins, however, were 15,000 times more effective on a concentration basis than sucrose, another known cryoprotectant (Carpenter and Crowe, 1988; Lee and Timasheff, 1981) and 15 times more effective than PEG. Heat-stable proteins from all Solanum species (from acclimated and nonacclimated plants studied, whether freezing tolerant or sensitive, demonstrated between $7.5 \times 10^{3}$ to $20 \times 10^{3}$ times greater cryoprotection

Table 3. Heat-stable and cryoprotective compound concentration necessary for $50 \%$ cyroprotection $\left(\mathrm{CP}_{50}\right)$ of lactate dehydrogenase (LDH) enzyme. Tests were conducted before (nonacclimated) and after cold acclimation period (acclimated). Heat stable proteins from Solanum species $\left(0-10 \mu \mathrm{g} \cdot \mathrm{mL}^{-1}\right)$ were combined with LDH enzyme, frozen, thawed and assayed for residual LDH activity. Values reported are derived from a third order polynomial fit line of residual activities (\%) over concentration range (see Fig. 2).

\begin{tabular}{|c|c|c|}
\hline \multirow{2}{*}{$\begin{array}{l}\text { Solanum } \\
\text { species }\end{array}$} & \multicolumn{2}{|c|}{$\begin{array}{c}\text { Heat stable protein } \\
\left(\mu \mathrm{g} \cdot \mathrm{mL}^{-1}\right) \text { for } \mathrm{CP}_{50} \text { of } \mathrm{LDH}\end{array}$} \\
\hline & Nonacclimated $^{\mathrm{z}}$ & Acclimated $^{\mathrm{y}}$ \\
\hline S. cardiophyllum (PI 184762) & $3.2 \pm 0.4$ & $2.7 \pm 0.5$ \\
\hline S. tuberosum L. Red Pontiac & $4.3 \pm 0.4$ & $4.6 \pm 0.5$ \\
\hline S. sanctae-rosea (PI 473200) & $3.9 \pm 0.5$ & $4.3 \pm 0.6$ \\
\hline S. acaule (PI 472659) & $2.0 \pm 0.3$ & $1.9 \pm 0.3$ \\
\hline S. commersonii (PI 472834) & $3.7 \pm 0.4$ & $2.0 \pm 0.4$ \\
\hline $\begin{array}{l}\text { Cryoprotective } \\
\text { compound }\end{array}$ & \multicolumn{2}{|c|}{$\begin{array}{l}\text { Concn }\left(\mu \mathrm{g} \cdot \mathrm{mL}^{-1}\right) \\
\text { for } \mathrm{CP}_{50} \text { of } \mathrm{LDH}\end{array}$} \\
\hline$\overline{\mathrm{BSA}}$ & \multicolumn{2}{|c|}{$7 \pm 4$} \\
\hline PEG & \multicolumn{2}{|c|}{$40 \pm 15$} \\
\hline Sucrose & \multicolumn{2}{|c|}{$4 \times 10^{4} \pm 1000$} \\
\hline Glycerol & \multicolumn{2}{|c|}{$>8 \times 10^{5}$} \\
\hline
\end{tabular}

zPlants were grown in a regime of $20 / 18^{\circ} \mathrm{C}$ day/night, $14 \mathrm{~h}$ light.

yPlants 6 weeks old grown at above conditions were cold acclimated in a regime of $4 / 2{ }^{\circ} \mathrm{C}$ day/night, $14 \mathrm{~h}$ light for $14 \mathrm{~d}$.

xPotato introduction (PI) identification number at the potato introduction station, Sturgeon Bay, Wis. 
Heat-stable protein $\left(\mu \mathrm{g} \cdot \mathrm{mL}^{-1}\right)$

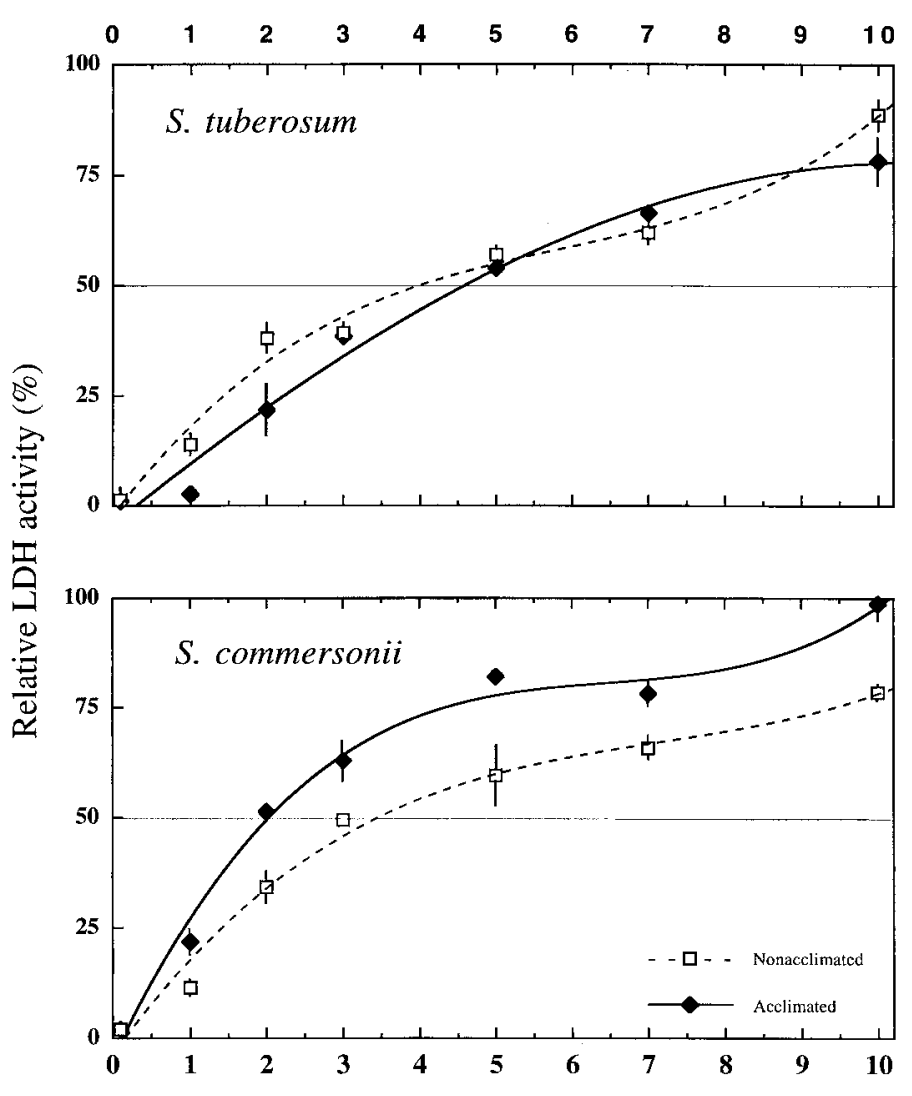

Heat-stable protein $\left(\mu \mathrm{g} \cdot \mathrm{mL}^{-1}\right)$

Fig. 3. Cryoprotection of freeze-labile enzyme lactate dehydrogenase (LDH) in a standard in vitro cryoprotection assay. Heat-stable protein extracts from $S$. tuberosum and $S$. commersonii grown in nonacclimated (open square, dashed line) and cold acclimated (black diamonds, solid line). Comparisons of qualitative differences between cryoprotective capacities of heat-stable protein fractions were based on concentration imparting 50\% cryoprotection (line drawn through $50 \%$ ). Lines are third-order polynomial fit and each point on graph based on quadruplicate assays. The error bars represent $\pm \mathrm{SE}$.

than sucrose, 7.5 to 20 times greater cryoprotection than PEG, and slightly greater cryoprotection than BSA (Table 3).

Activation of LDHEnzyme by a high concentration of heat-stable proteins. In addition to the range $\left(0-10 \mu \mathrm{g} \cdot \mathrm{mL}^{-1}\right)$, a single higher concentration of heat-stable proteins $\left(50 \mu \mathrm{g} \cdot \mathrm{mL}^{-1}\right)$ was assayed. When extracts from acclimated $S$. commersonii and $S$. sanctae rosea were added to LDH, enzyme activity was above prefreeze levels (Fig. 5). Heat-stable proteins from $S$. commersonii and $S$. sanctae rosea in the acclimated state elevated LDH to $120 \%$ compared to $87 \%$ and $95 \%$, respectively, from the nonacclimated state. Heat-stable proteins from the other species did not demonstrate activation of LDH. Solanum tuberosum, though unable to cold acclimate, demonstrated greater cryoprotection after cold acclimation (Fig. 5). Heat-stable proteins extracted from freezing-sensitive $S$. cardiophyllum showed higher cryoprotective activity than freezing tolerant $S$. acaule. None of the other standard cryoprotectants (BSA, PEG, glycerol, and sucrose) activated LDH above prefreeze levels at $50 \mu \mathrm{g} \cdot \mathrm{mL}^{-1}$.

\section{Discussion}

By exploiting the genetic variation in NA RFT and ACC in five tuber-bearing Solanum species, we were able to gain new insight into the complexity of the relationship between heat-stable proteins and cold response. Dehydrin, a highly conserved, dehydrative stress response protein cannot alone explain the ability of these species to survive freezing under nonacclimated growth conditions and following cold acclimation. Amidst the complexity of heat-stable protein expression in these species, however, is the data obtained from the LDH cryoprotection study which indicate that other heat-stable proteins, or unidentified heat-stable components, may be important factors in the freezing tolerance of tuberbearing Solanum species.

HEAT-STABLE PROTEIN EXPRESSION NOT A SOLE FACTOR CONFERRING FREEZING TOLERANCE. Quantitative differences in heat-stable protein concentration among five Solanum species did not correspond to either NA RFT or AC RFT. In general agreement with the literature, however, heat-stable protein expression increased during cold acclimation in all species. Previous studies used only species capable of cold acclimation. By including nonacclimating species we were able to provide the required controls for relating ACC to heat-stable proteins and to assess the cryoprotective capacity of the heat-stable protein fraction. It is important to point out that repeated measurements of RFT on these clonally propagated Solanum genotypes do not vary by more than $\pm 0.2{ }^{\circ} \mathrm{C}$ (Stone et al., 1993).

Heat-stable protein increase in $S$. cardiophyllum and $S$. tuberosum may be a general stress response-with no ability to increase $\mathrm{ACC}$ for these species. It is possible that these species are acclimating to suboptimal growth conditions (low temperature and light) and becoming more resistant to other stresses, such as oxidative or disease stress. This suggestion warrants further study of the species included in this study.

DEHYDRIN PROTEIN EXPRESSION IN TUBER-BEARING SolanUm SPECIES. Though our results do not rule out a role for dehydrin proteins in freezing tolerance in Solanum species studied, it does not

Fig 4. Standards of known cryoprotective capacity compared to heat-stable proteins from cold acclimated $S$. commersonii in a standard in vitro cryoprotective assay. Using cryoprotection of freeze-labile enzyme lactate dehydrogenase (LDH), heat-stable proteins from cold acclimated Solanum commersonii, BSA, PEG, sucrose, and glycerol were assayed for activity. Each point on graph is the average of quadruplicate assays and error bars represent \pm SE.

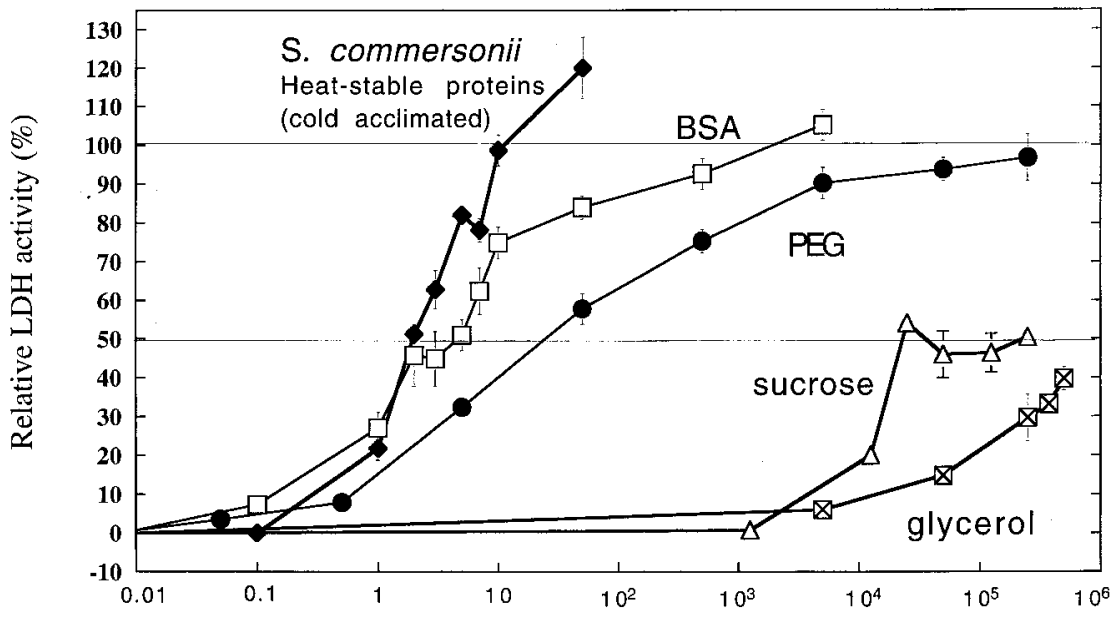

Concentration of cryoprotective molecule $\left(\mu \mathrm{g} \cdot \mathrm{mL}^{-1}\right)$ 


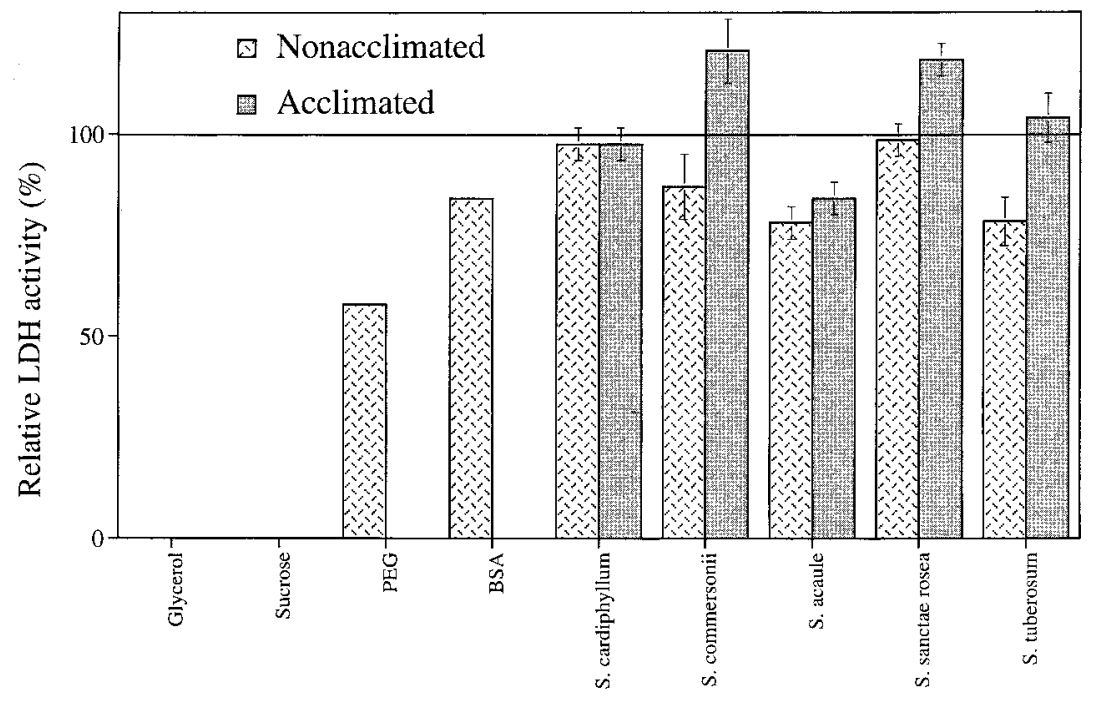

Cryoprotective compound/ BSP (concn. $50 \mu \mathrm{g} \cdot \mathrm{mL}^{-1}$ ) proteins and freezing tolerance of the five species studied. However, it is interesting to note that $S$. commersonii, the species that had the highest acclimation capacity, demonstrated the highest change in cryoprotective behavior of the heat-stable proteins. Also, following cold acclimation, heat-stable proteins from freezing-sensitive, nonacclimating $S$. tuberosum L. 'Red Pontiac' were half as effective for $50 \%$ cryoprotection as compared to freezing tolerant and acclimation able $S$. acaule and $S$. commersonii. Results of our study (Table 3, Fig. 3) demonstrate that while differences in heat-stable protein fractions from different species vary in their ability to cryoprotect LDH, heat-stable proteins from the most cold-sensitive Solanum species have the capacity to cryoprotect LDH many times more effectively than some known cryoprotectants (glycerol, sucrose, and PEG). These species may utilize heatstable proteins as a heat-tolerance mechanism though this was not determined in our study.

Previous studies using LDH assays to study coldregulated proteins have reported protein concentra-

Fig. 5. Cryoprotection and activation of lactate dehydrogenase (LDH) enzyme by a high concentration of heat-stable proteins. In a standard in vitro cryoprotective assay, heat-stable proteins $\left(50 \mu \mathrm{g} \cdot \mathrm{mL}^{-1}\right)$ from five Solanum species from nonacclimated and cold acclimated plants as well as cryoprotective standards were assayed for activity. Activation is defined as activity above prefreeze values (100\%). Standards include glycerol, sucrose, PEG, and BSA. At a concentration of $50 \mu \mathrm{g} \cdot \mathrm{mL}^{-1}$, glycerol and sucrose were not sufficient to cryoprotect the LDH enzyme (see Fig. 4). The error bars represent \pm sE.

appear that dehydrin alone can explain the range of freezing tolerances in our materials. Cold acclimation treatment resulted in increased dehydrin expression for both acclimating and nonacclimating species. Dehydrins may contribute to an increase in freezing tolerance during cold treatment in three of the species ( $S$. acaule, S. sanctae rosea, and S. commersonii). In the cold sensitive, nonacclimating species $S$. tuberosum and $S$. cardiophyllum, however, an increase in dehydrin level was unable to improve freezing tolerance and was likely related to the changed environment during cold treatment. In several studies, an association was established between increased dehydrin protein expression and increase in hardiness during cold acclimation (Artlip et al., 1997; Artus et al., 1996; Boothe et al., 1995; Danyluk et al., 1994; Robertson et al., 1994; Salzman et al., 1996). This association does not appear to hold, however, for the species used in our study. In support of our results, a recent study reported geranium Pelargonium $\times$ hortorum 'Evening Glow', a noncoldacclimating plant, increased expression of a $45-\mathrm{kD}$ dehydrin following cold acclimation (Arora et al., 1998). Also, in the same study a 70-kD heat-shock cognate protein (HSC70) increased expression without a rise in heat-stress tolerance. This study suggests that increases in certain heat-stable proteins (both dehydrin and heat shock) may be due to a general stress response and not enhance plant stress tolerance. In further support of our results, Baudo et al. (1996) found dehydrin gene transcript accumulation from hardy, cold-acclimating S. commersonii and sensitive, nonacclimating S. tuberosum to be $96 \%$ homologous and to be expressed equally as a $1-\mathrm{kb}$ transcript during cold acclimation. As our results indicate no difference in dehydrin expression between S. commersonii and S. tuberosum, it would be interesting to determine whether the gene in Baudo et al. (1996) produces the protein detected in our study.

LDH CRYOPROTECTIVE ASSAY. There was no systematic relationship between the cryoprotective capacity of the heat-stable tions for $\mathrm{CP}_{50} 100$ times more effective than BSA for COR15a (Lin and Thomashow, 1992), three times more effective than BSA for COR85 (Kazuoka and Oeda, 1994), and equal to BSA for WSC120 (Houde et al., 1995). It is important to point out that other studies using the LDH cryoprotective assay have employed pure protein whereas our study used a mixture of heat-stable proteins, suggesting the presence of a potent cryoprotective component.

It is intriguing that $\mathrm{LDH}$ is activated $20 \%$ to $30 \%$ above the prefreeze value when combined with heat-stable proteins from acclimated $S$. commersonii and $S$. sanctae rosea. The LDH activity in the presence of nonacclimated heat-stable proteins from the same species did not reach the prefreeze value (Fig. 5). A similar case was reported for ATPase activity of actomyosin (Tsuchiya et al., 1975) and was attributed to a slight transconformation (unfolding) in the area of active sites of enzyme molecules due to the effect of freezing. Further studies are needed to explain this interesting observation for these species.

In general, our findings of an increase in heat-stable proteins following cold acclimation are in agreement with earlier results. However, our results show that the quantitative increase in heatstable proteins during cold acclimation may not be responsible for the quantitative changes in freezing tolerance following cold acclimation. Dehydrin expression was not correlated to either NA RFT or AC RFT. For all the potato species, the heat-stable protein fraction was effective in decreasing the level of freeze-induced inactivation of $\mathrm{LDH}$ in vitro. At a higher heat-stable protein concentration, we found activation of LDH only following cold acclimation for some cold hardy species. Use of the five Solanum species has provided us a good tool to gain valuable new information on the complexity of the role of dehydrin and heat-stable proteins in frost hardiness.

\section{Literature Cited}

Arora, R., D.S. Pitchay, and B.C. Bearce. 1998. Water-stress-induced heat tolerance in geranium leaf tissues: A possible linkage through stress proteins? Physiol. Plant. 103:24-34.

Arora, R. and M.E. Wisniewski. 1994. Cold acclimation in genetically related (sibling) deciduous and evergreen peach [Prunus persica (L.) Batsch]. II. A 60-kilodalton bark protein in cold-acclimated tissues of peach is heat-stable and related to the dehydrin family of proteins. Plant Physiol. 105:95-101. 
Artlip, T.S., A.M. Callahan, C.L. Bassett, and M.E. Wisniewski. 1997. Seasonal expression of a dehydrin gene in sibling deciduous and evergreen genotypes of peach [Prunus persica (L.) Batsch]. Plant Mol. Biol. 33:61-70.

Artus, N.N., M. Uemura, P.L. Steponkus, S.J. Gilmour, C. Lin, and M.F. Thomashow. 1996. Constitutive expression of the cold-regulated Arabidopsis thaliana COR15a gene affects both chloroplast and protoplast freezing tolerance. Proc. Natl. Acad. Sci. USA 93:13404-13409.

Baudo, M.M., L.A. Meza-Zepeda, E.T. Palva, and P. Heino. 1996. Induction of homologous low-temperature and ABA-responsive genes in frost resistant (Solanum commersonii) and frost-sensitive (Solanum tuberosum cv. Bintje) potato species. Plant Mol. Biol. 30:331-336.

Birkett, C.R., K.E. Foster, L. Johnson, and K. Gull. 1985. Use of monoclonal antibodies to analyze the expression of a multi-tubulin family. Fed. Eur. Biochem. Soc. Lett. 187:211-218.

Blackman, S.A., R.L. Obendorf, and A.C. Leopold. 1995. Desiccation tolerance in developing soybean seeds: The role of stress proteins. Physiol. Plant. 93:630-638.

Boothe, J.G., M.D. de Beus, and A.M. Johnson-Flanagan. 1995. Expression of a low-temperature-induced protein in Brassica napus. Plant Physiol. 108:795-803.

Carpenter, J.F. and J.H. Crowe. 1988. The mechanism of cryoprotection of proteins by solutes. Cryobiology 25:244-255.

Chen, H.H. and P.H. Li. 1980. Biochemical changes in tuber-bearing Solanum species in relation to frost hardiness during cold acclimation. Plant Physiol. 66:414-421.

Close, T.J., R.D. Fenton, and F. Moonan. 1993. A view of plant dehydrins using antibodies specific to the carboxy terminal peptide. Plant Mol. Biol. 23:279-286.

Close, T.J., A.A. Kortt, and P.M. Chandler. 1989. A cDNA-based comparison of dehydration-induced proteins (dehydrins) in barley and corn. Plant Mol. Biol. 13:95-108.

Danyluk, J., M. Houde, E. Rassart, and F. Sarhan. 1994. Differential expression of a gene encoding an acidic dehydrin in chilling sensitive and freezing tolerant gramineae species. Fed. Eur. Biochem. Soc. Lett. 344: 20-24.

Grieff, D. and R.T. Kelly. 1966. Cryotolerance of enzymes: I. Freezing of lactic dehydrogenase. Cryobiology 2:355-341.

Guy, C.L. 1990. Cold acclimation and freezing stress tolerance: Role of protein metabolism. Annu. Rev. Plant Physiol. Plant Mol. Biol. 41:187223.

Hoagland, D.R. and D.I. Arnon. 1950. The water culture method of growing plants without soil. Calif. Agr. Expt. Sta. Circ. 347.

Houde, M., C. Daniel, M. Lachapelle, F. Allard, S. Laliberte, and F. Sarhan. 1995. Immunolocalization of freezing-tolerance-associated proteins in the cytoplasm and nucleoplasm of wheat crown tissues. Plant J. 8:583-593.

Jacobsen, J.V. and D.C. Shaw. 1989. Heat-stable proteins and abscisic acid action in barley aleurone cells. Plant Physiol. 91:1520-1526.

Jaglo-Ottosen, K.R., S.J. Gilmour, D.G. Zarka, O. Schabenberger, and M.F. Thomashow. 1998. Arabidopsis CBF1 overexpression induces COR genes and enhances freezing tolerance. Science 280:104-106.

Karlsson, B.H., J.P. Palta, L.S. Weiss, J.F. Harbage, and J.B. Bamberg. 1994. Differential expression of dehydrin (47 KD) 'boiling-stable' protein within populations of two diploid potato species segregating for cold tolerance and acclimation capacity. HortScience 29:563 (abstr.).

Kawczynski, W. and R.S. Dhindsa. 1996. Alfalfa nuclei contain coldresponsive phosphoproteins and accumulate heat-stable proteins during cold treatment of seedlings. Plant Cell Physiol. 37:1204-1210.
Kazuoka, T. and K. Oeda. 1994. Purification and characterization of COR85-oligomeric complex from cold-acclimated spinach. Plant Cell Physiol. 35:601-611.

Lee, J.C. and S.N. Timasheff. 1981. Stabilization of proteins by sucrose. J. Biol. Chem. 256:7193-7201.

Lee, G.J., M. Pokala, and E. Vierling. 1995. Structure and in vitro molecular chaperone activity of cytosolic small heat-shock proteins from pea. J. Biol. Chem. 270:10432-10438.

Lin, C. and M.F. Thomashow. 1992. A cold-regulated Arabidopsis gene encodes a polypeptide having potent cryoprotective activity. Biochem. Biophys. Res. Commun. 183:1103-1108.

Lowry, O.H., N.J. Rosebrough, A.L. Farr, and R.J. Randall. 1951. Protein measurement with the Folin phenol reagent. J. Biol. Chem 193:262275.

Murashige, T. and F. Skoog. 1962. A revised medium for rapid growth and bioassays with tobacco tissue cultures. Physiol. Plant. 15:473-497.

Palta, J.P., H.H. Chen, and P.H. Li. 1981. Relationship between heat and frost resistance of tuber-bearing Solanum species: Effect of cold acclimation on heat resistance. Bot. Gaz. 142:311-315.

Pan, A., P.M. Hayes, F. Chen, T.H.H. Chen, T. Blake, S. Wright, I. Karsai, and Z. Bedo. 1994. Genetic analysis of the components of winterhardiness in barley (Hordeum vulgare L.). Theor. Appl. Genet. 89:900-910.

Polacheck, I. and E. Cabib. 1981. A simple procedure for protein determination by the Lowry method in dilute solutions and in the presence of interfering substances. Anal. Biochem. 117:311-314.

Robertson, M. and P.M. Chandler. 1994. A dehydrin cognate protein from pea (Pisum sativum L.) with an atypical pattern of expression. Plant Mol. Biol. 26:805-816.

Robertson, A.J., M.M. Ishikawa, L.V. Gusta, and S. Mackenzie. 1994. Abscisic acid-induced heat tolerance in Bromus inermis Leyss cellsuspension cultures. Plant Physiol. 105:181-190.

Salzman, R.A., R.A. Bressan, P.M. Hasegawa, E.N. Ashworth, and B.P. Bordelon. 1996. Programmed accumulation of LEA-like proteins during desiccation and cold acclimation of overwintering grape buds. Plant Cell Environ. 19:713-720.

Steffan, K.L. and J.P. Palta. 1986. Effect of light on photosynthetic capacity during cold acclimation in a cold-sensitive and cold-tolerant potato species. Physiol. Plant. 66:353-359.

Stone, J.M., J.P. Palta, J.B. Bamberg, L.S. Weiss, and J.F. Harbage. 1993. Inheritance of freezing resistance in tuber-bearing Solanum species: Evidence for independent genetic control of nonacclimation freezing tolerance and cold acclimation capacity. Proc. Natl. Acad. Sci. USA 90:7869-7873.

Sutinen, M.L., J.P. Palta, and P.B. Reich, 1992. Seasonal differences in freezing stress resistance of needles of Pinus nigra and Pinus resinosa: Evaluation of the electrolyte leakage method. Tree Physiol. 11:241254.

Tamiya, T., N. Okahashi, R. Sakuma, T. Aoyama, T. Akahane, and J.J. Matsumoto. 1985. Freeze denaturation of enzymes and its prevention with additives. Cryobiology 22:446-456.

Thomashow, M.F., S.J. Gilmour, and C. Lin. 1993. Cold-regulated genes in Arabidopsis, p. 31-44. In: P.H. Li and L. Christersson (eds.). Advances in plant cold hardiness. CRC Press, Boca Raton, Fla.

Tsuchiya, T., Y. Tsuchiya, Y. Nonomura, and J.J. Matsumoto. 1975. Prevention of freeze denaturation of carp actomyosin by sodium glutamate. J. Biochem. 77:853-862.

Volger, H.G. and U. Heber. 1975. Cryoprotective leaf proteins. Biochim. Biophys. Acta 412:335-349. 